\title{
Investigation on Current Situation of College Students' Interpersonal Communication
}

\author{
Yu Zhao \\ Department of Psychology \\ Faculty of Humanities \\ Gannan Medical University \\ Ganzhou, China, 341000
}

\author{
Wen $\mathrm{Hu}$ \\ Department of Psychology \\ Faculty of Humanities \\ Gannan Medical University \\ Ganzhou, China, 341000 \\ Tiechuan Liu \\ Gannan Normal University \\ Ganzhou, China
}

\author{
Xiaorong Gan \\ Department of Psychology \\ Faculty of Humanities \\ Gannan Medical University \\ Ganzhou, China, 341000 \\ Ming Cheng \\ Department of Psychology \\ Faculty of Humanities \\ Gannan Medical University \\ Ganzhou, China, 341000
}

\begin{abstract}
The Comprehensive Diagnostic Scale for Interpersonal Relationship of College Students compiled by Zheng Richang is used in this research to carry out questionnaire survey for 311 college students of Gannan Medical University. Conclusion: The interpersonal communication of college students in Gannan Medical University is ordinary with average composite score of $\mathbf{1 0 . 4 5}$.
\end{abstract}

Keywords-college students; interpersonal relationship; personal characteristics

\section{INTRODUCTION}

College students are a special group. The differences in interpersonal communication of college students in Gannan Medical University in sex, grade and town and country are analyzed to provide solutions for educational problems in interpersonal communication.

\section{RESEARCH METHOD}

\section{A. The Subjectsto be Sampled}

The subjects are undergraduates from freshman to senior of Gannan Medical University. About 90 questionnaires are distributed to each grade. There are 360 questionnaires distributed in total. 334 questionnaires are collected with recovery rate of $92 \%$. There are 23 invalid questionnaires that students fail to complete or only give the answer of "yes" or "no", 311 valid questionnaires with effective rate of $93 \%$.

\section{B. Research Tool}

The Comprehensive Diagnostic Scale for Interpersonal Relationship of College Students is compiled by Zheng Richang. It relates to behavior disturbance of interpersonal relationship and has 28 questions with positive scores. Students can get one point if answering "yes" and get zero point if answering "no". The total score represents the degree of behavior disturbance of interpersonal relationship. The severity of disturbance improves with the increase of scores. The degree of behavior disturbance consists of three levels. 0 to 8 scores, it shows students have low degree of behavior disturbance and good interpersonal relationship; 9 to 14 scores, it shows students have some degree of behavior disturbance and ordinary interpersonal relationship; 15 to 28 scores, it shows students are weak in getting along with others and have poor interpersonal relationship. The 28 questions cover four aspects of interpersonal communication with 7 questions and 7 scores for each aspect, including conversation with others, communication with others, relationship with the opposite sex and manner of dealing with people. The higher the score in some aspect, the more disturbances and the poorer interpersonal relationship the subjects will have.

\section{Data Processing}

Data are processed through SPSS20.0 for Windows. 


\section{RESEARCH RESULTS}

\section{A. Overall Condition of College Students' Interpersonal} Relationship in Gannan Medical University

The overall interpersonal relationship of college students in Gannan Medical University is unsatisfactory. The score of the Comprehensive Diagnostic Scale for Interpersonal Relationship of College Students is 10.7, showing the subjects have some disturbance in interpersonal communication and ordinary interpersonal relationship. As shown in "Table I".

TABLE I. OVERALL CONDITION OF INTERPERSONAL RELATIONSHIP $(\mathrm{N}=311)$

\begin{tabular}{lllll}
\hline Variable & $\begin{array}{c}\text { Average } \\
\text { number }\end{array}$ & $\begin{array}{c}\text { Maximum } \\
\text { value }\end{array}$ & $\begin{array}{c}\text { Minimum } \\
\text { value }\end{array}$ & $\begin{array}{c}\text { Standard } \\
\text { deviation }\end{array}$ \\
\hline $\begin{array}{l}\text { Interpersonal } \\
\text { relationship }\end{array}$ & 10.7 & 25 & 1 & 5.34 \\
\hline
\end{tabular}

\section{B. Differences of Aspects in Interpersonal Relationship in Sex}

On the variable of sex, except for conversation, great differences exist in the other three aspects. Female students get lower scores than male students in communication with others, relationship with the opposite sex and manner of dealing with people. It states female students have fewer disturbances in interpersonal communication in the three aspects. As shown in "Table II".

TABLE II. COMPARISON OF ASPECTS IN INTERPERSONAL RELATIONSHIP IN VARIABLE OF SEX $(\mathrm{N}=311)$

\begin{tabular}{|c|c|c|c|c|c|}
\hline \multirow[t]{3}{*}{ Variable } & \multicolumn{5}{|c|}{ Sex } \\
\hline & \multicolumn{2}{|c|}{ Male $(n=118)$} & \multicolumn{2}{|c|}{ Female $(n=193)$} & \multirow[b]{2}{*}{$t$} \\
\hline & $M$ & $S D$ & $M$ & $S D$ & \\
\hline Communication & 3.39 & 1.75 & 3.31 & 1.93 & 0.386 \\
\hline Conversation & 3.19 & 1.70 & 2.67 & 1.78 & $2.548^{*}$ \\
\hline $\begin{array}{l}\text { Manner of dealing with } \\
\text { people }\end{array}$ & 2.20 & 1.78 & 1.70 & 1.39 & $2.759 *$ \\
\hline $\begin{array}{l}\text { Relationship with the } \\
\text { opposite sex }\end{array}$ & 2.99 & 1.86 & 2.04 & 1.72 & $2.749 * *$ \\
\hline $\begin{array}{l}\text { Total scores of } \\
\text { interpersonal } \\
\text { relationship }\end{array}$ & 11.76 & 5.38 & 9.64 & 5.17 & $3.455^{* *}$ \\
\hline Communication & 3.39 & 1.75 & 3.31 & 1.93 & 0.386 \\
\hline Conversation & 3.19 & 1.70 & 2.67 & 1.78 & $2.548^{*}$ \\
\hline $\begin{array}{l}\text { Manner of dealing with } \\
\text { people }\end{array}$ & 2.20 & 1.78 & 1.70 & 1.39 & $2.759 *$ \\
\hline $\begin{array}{l}\text { Relationship with the } \\
\text { opposite sex }\end{array}$ & 2.99 & 1.86 & 2.04 & 1.72 & $2.749 * *$ \\
\hline $\begin{array}{l}\text { Total scores of } \\
\text { interpersonal } \\
\text { relationship }\end{array}$ & 11.76 & 5.38 & 9.64 & 5.17 & $3.455 * *$ \\
\hline
\end{tabular}

TABLE III. COMPARISON OF ASPECTS IN INTERPERSONAL RELATIONSHIP IN VARIABLE OF GRADE (N=311)

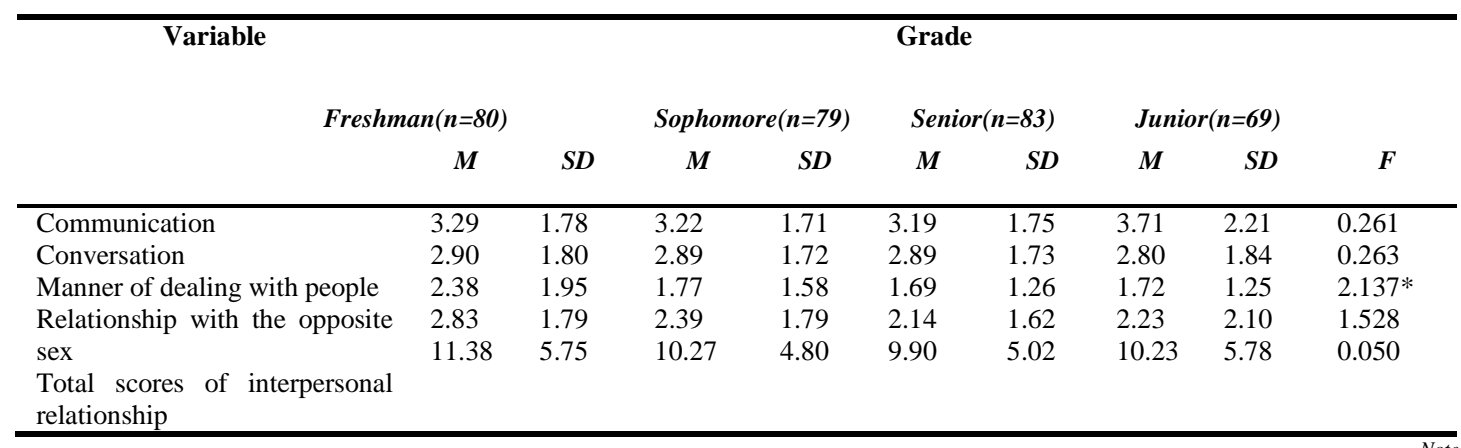

TABle IV. Multiple Comparisons of Manner of Dealing With PeOPle in VARiable of Grade (N=311)

\begin{tabular}{|c|c|c|c|c|c|}
\hline Dependent variable & Grade (I) & Grade (J) & Mean difference (I-J) & Standard error & Significance \\
\hline \multirow{3}{*}{\multicolumn{2}{|c|}{$\begin{array}{l}\text { Manner of dealingFreshman }(n=80) \\
\text { with people }\end{array}$}} & Sophomore & $0.60285^{*}$ & 0.24497 & 0.014 \\
\hline & & Junior & $0.68825^{*}$ & 0.24198 & 0.005 \\
\hline & & Senior & $0.65036^{*}$ & 0.25374 & 0.011 \\
\hline \multirow{3}{*}{\multicolumn{2}{|c|}{ Sophomore $(n=79)$}} & Freshman & $-0.60285^{*}$ & 0.24497 & 0.014 \\
\hline & & Junior & 0.08540 & 0.24276 & 0.725 \\
\hline & & Senior & 0.04751 & 0.25448 & 0.852 \\
\hline \multirow{3}{*}{\multicolumn{2}{|c|}{ Junior( $n=83$ ) }} & Freshman & $-0.68825 *$ & 0.24198 & 0.005 \\
\hline & & Sophomore & -0.08540 & 0.24276 & 0.725 \\
\hline & & Senior & -0.03789 & 0.25161 & 0.880 \\
\hline \multirow{3}{*}{\multicolumn{2}{|c|}{ Senior $(n=69)$}} & Freshman & $-0.65036^{*}$ & 0.25374 & 0.011 \\
\hline & & Sophomore & -0.04751 & 0.25448 & 0.852 \\
\hline & & Senior & 0.03789 & 0.25161 & 0.880 \\
\hline
\end{tabular}




\section{Differences of Interpersonal Relationship from Each Aspect in Grade}

On the variable of grade, only the manners of dealing with people are greatly different. It discovers through comparison between any two means that freshman is greatly different from sophomore, junior and senior and gets higher scores than the rest. It shows the freshmen are immature in interpersonal communication and poor interpersonal skills. As shown in "Table III" and "Table IV".

\section{Differences of Interpersonal Relationship from Each Aspect in Town and Country}

On the variable of town and country, except for the manner of dealing with people, the other three aspects are greatly different. College students from rural areas get higher scores in the three aspects. It shows college students from cities have fewer disturbances than that from rural areas in aspects of interpersonal relationship. As shown in "Tble V"

TABLE V. COMPARISON OF ASPECTS IN INTERPERSONAL RELATIONSHIP IN THE VARIABLE OF TOWN AND COUNTRY $(\mathrm{N}=311)$

\begin{tabular}{|c|c|c|c|c|c|}
\hline \multirow[t]{3}{*}{ Variable } & \multicolumn{5}{|c|}{ Town and country } \\
\hline & \multicolumn{2}{|c|}{$\begin{array}{l}\text { Town } \\
(n=84)\end{array}$} & \multicolumn{2}{|c|}{ Country $(n=227)$} & \multirow[b]{2}{*}{$t$} \\
\hline & $M$ & $S D$ & $M$ & $S D$ & \\
\hline Communication & 2.86 & 1.71 & 3.52 & 1.71 & $-2.930 * *$ \\
\hline Conversation & 2.39 & 1.80 & 3.05 & 1.72 & $-2.789 * *$ \\
\hline $\begin{array}{l}\text { Manner of dealing with } \\
\text { people }\end{array}$ & 1.72 & 1.62 & 1.96 & 1.54 & -1.151 \\
\hline $\begin{array}{l}\text { Relationship with the } \\
\text { opposite sex }\end{array}$ & 1.93 & 1.78 & 2.58 & 1.82 & $-2.805 * *$ \\
\hline $\begin{array}{l}\text { Total scores of } \\
\text { interpersonal relationship }\end{array}$ & 8.90 & 5.52 & 11.02 & 5.17 & $-2.605 * *$ \\
\hline
\end{tabular}

\section{DISCUSSION}

\section{A. Explanation for the Differences of Interpersonal Relationship in Sex, Grade, Town and Country}

The differences of interpersonal relationship are obvious in sex, town and country and not obvious in grade. Although it differs from the scale used in the existing research, the influence factor cannot be verified. The reason why the differences are not obvious in the variable of grade is that the research objects are different. Students in medical college have heavy learning tasks and take many courses in the four years. They spend most of the time in learning instead of interpersonal relationship. The scores of subjects' interpersonal relationship have no difference in grade. The average score is lower than that of the existing research.

\section{B. Reasons for Differences of Conversation in Variables of Sex, Grade, Town and Country}

The differences in scores of conversation are not obvious in grade and sex but obvious in town and country. The super high score in conversation shows students cannot properly express their ideas and listen to others. The differences in town and country are because of the different living environment. Students from rural areas seldom express their ideas.

\section{Reasons for Differences of Intercourse in Variables of Sex, Grade, Town and Country}

The score differences of intercourse are obvious in town and country and sex. It reflects the problems in social contact and making friends. It is similar to the conversation. Students from rural areas seldom make contact with others and have little experience, so that they fail to make friends actively.

\section{Reasons for Differences of Manner of Dealing with People in Variables of Sex, Grade, Town and Country}

The differences of the manner of dealing with people are obvious in grade and sex but not obvious in town and country. Although students from rural areas are not experienced in conversation and communication, they have basic politeness and skills in dealing with people.

\section{E. Reasons for Differences of Relationship with the Opposite} Sex in Variables of Sex, Grade, Town and Country

The differences of relationship with the opposite sex are not obvious in grade but obvious in town and country and sex. The disturbance in relationship with the opposite sex means students fail to know how to get along with the opposite sex, treat the opposite sex with prejudice or don't know the degree of intimacy. Students from freshman to senior have got along with the opposite sex for more than ten years and some have close friends of the opposite sex. The differences in grade are not obvious on the whole. The reason why the differences are obvious in town and country is that the cultural backgrounds differ. Students growing up in towns are opener and feel more unrestrained in getting along with the opposite sex. Female students are easier to begin the conversation. The degree of intimacy between male and female students is decided by the female students.

\section{CONCLUSion}

Except for college students' efforts, colleges can provide more opportunities for students to improve their interpersonal skills. Courses and lectures can be provided to teach theoretical knowledge of interpersonal communication, in order to lay a solid foundation for students and enhance their confidence in communication. Furthermore, organizations in colleges can carry out outdoor training to give group guidance and provide a platform for students to apply theory to practice and improve their interpersonal skills.

\section{REFERENCES}

[1] Qin Hongxia, Gao Feng. Research Status and Development of College Students' Interpersonal Skills [J], Higher Education and Higher Vocational Education Research, 2009: 207-209

[2] Zheng Kai, He Yuanqing. Experimental Research on Group Psychology Counseling to Improve College Students' Interpersonal Relationship [J], China Journal of Health Psychology, 2009, 17(8): 985-986

[3] Gao Ying. Research on Problems in College Students' Interpersonal Communication [D], master's thesis of Liaoning University, 2012: 2534 
[4] Zhao Qian. Analysis on Current Situation of College Students' Interpersonal Communication and Empirical Research on Training of College Students' Ability in Interpersonal Communication [D], master's thesis of Shandong University, 2012: 26-44 